\author{
T. Momot, O. VashChenKo, R. Teslenko, D. Momot
}

\title{
STRATEGIC MONITORINGOF OF THE EXTERNAL ENVIRONMENT IN THE SYSTEM OF ENSURING THE FINANCIAL AND ECONOMIC SECURITY OF THE STATE, REGION, ENTERPRISE
}

The subject of the study in the article is a comprehensive analysis of the external environment in terms of the country's competitiveness. The goal of the work is to substantiate the scientific and methodological foundations of a comprehensive analysis of the external environment according to the level of a country's competitiveness within the framework of strategic monitoring in the system of ensuring the financial and economic security of the state, the region, and business entities. The following tasks were solved in the article: reasonably hierarchical relations in the process of strategic monitoring implementing in the financial and economic security ensuring system of the state, region, business entities; reviewed the hierarchy of strategic monitoring levels in the system of national economic security; characterized by information flows of the strategic monitoring organization levels; describes the process of using information by economic entities at various levels of government in order to implement strategic monitoring; systematized international approaches to the construction of competitiveness countries ratings; analyzed the place of Ukraine in international competitiveness ratings. The following methods are used: abstract logical analysis, theoretical generalization, system and statistical analysis. The following results were obtained: we proved that the strategic monitoring at the regional and local levels, as a rule, has hierarchical relationship with the inherent characteristics of all hierarchical systems; the economic security of any economic entity is formed under the influence of environmental factors at the global, national and regional levels; a country's competitiveness is considered as a set of properties inherent in the national economy, which determine a country's ability to compete with other countries; according to the analysis of key international ratings of competitiveness of the country, Ukraine first of all needs to concentrate its efforts on fighting against corruption and rational macroeconomic policies implementing. Conclusions: strategic monitoring in the system of the financial and economic security ensuring of the state, region, business entities in the framework of conducting a system analysis and forecasting changes in the global competitiveness of countries should be a significant measure of the system-integrated implementation to counter existing threats to ensure the state national interests protection as the basis viability and conditions for further progressive country development.

Keywords: strategic monitoring; country competitiveness; financial and economic security; international competitiveness ratings; comprehensive analysis.

\section{Introduction}

The consolidation of Ukraine's course towards the North Atlantic Alliance and the European Union in the Constitution of Ukraine defined the country's foreign policy strategy. The choice of a development vector towards a European civilization model contributes to progress in all spheres of society and the state, approximates the standards of democracy, the information society, a competitive and socially oriented market economy based on the principles of the rule of law and the safeguarding of human and civil rights and freedoms. Due to the urgent need to ensure national security, the establishment and development of an integrated system of strategic monitoring and audit support for the establishment of the organizational and legal framework for the development of the sphere of security according to European standards, blocking the preconditions for the criminalization of economic relations and creating a favorable investment climate is seen as a priority task. Considering the importance of adapting the system of financial and economic security of the state, region, business entities of Ukraine to the international security space, the important task is the development and practical implementation of European tools for evaluating and strategic monitoring of the level of financial and economic security, a systematic analysis of corruption risks, combining efforts and ensuring effective interaction on the implementation of state anti-corruption policy in the development of the European vector of foreign policy.

\section{Analysis of recent research and publications}

The importance of the question of the financial and economic security of the state, the region, economic entities in the modern conditions is substantiated in the works of such scholars as Bilik R. I. [1], Vlasyuk O. S. [2], Krylenko I.V. [3] Muntian V.I. [4], V.B. Podborsky [5], Sak T.V. [6], Timoshenko O.V. [7] and others.

The works of scientists substantiate the fundamental aspects of the system of ensuring financial and economic security, which helps to improve the tools for assessing the level of financial and economic security of the state, region and economic entities in accordance with the parameters of the dynamic environment and causes the relevance of the study of this problem.

In the circumstances necessary and timely, research and improvement of the process of implementing strategic analytics and audit support in the system of providing financial and economic security of Ukraine in the context of the application of European standards of security and anti-corruption management.

\section{Formulating the goals of the article (statement of the task)}

The aim of the work is to deepen the scientific and methodical principles of a comprehensive analysis of the environment on the level of competitiveness of the country in the framework of strategic monitoring in the system of ensuring financial and economic security of the state, region, economic entities. Achievement of the set 
goal set the following tasks: to substantiate the hierarchy of connections in the process of strategic monitoring in the system of providing financial and economic security of the state, region, economic entities; to consider the hierarchy of levels of strategic monitoring in the system of national economic security; to detail information flows of levels of organization of strategic monitoring; describe the process of using information by economic entities at the micro, meso and macro levels in order to carry out strategic monitoring and management; systematize international approaches to constructing country competitiveness ratings; to analyze Ukraine's place in international competitiveness ratings.

\section{Materials and methods}

Theoretical and methodological basis of the research were the scientific works and informational and analytical materials of the leading domestic scientists and foreign scientists-economists in the field of analysis of the environment on the level of competitiveness of the country. In the course of the research, the following methods were used: abstract-logical analysis - for a theoretical generalization and justification of research directions and results; theoretical generalization - to study the features of the analysis of the environment on the level of competitiveness of the country using international ratings; system and statistical analysis - for the analysis of Ukraine's rating by international competitiveness indices.

\section{Presentation of the main research material}

At various levels of managerial decision making, there is always a significant number of problem situations that are characterized by high uncertainty of occurrence; considerable complexity and uniqueness of the conditions; a large number of parameters that need to be taken into account during their analysis; contradictory criteria for selecting an optimal alternative solution to the problem; the complexity of predicting the consequences of implementing possible alternatives; limited time to decide.

Based on the peculiarities of the emerging problems, the urgent need is to create an effective system of strategic monitoring of economic security at the state, regional and local levels as an integrated system of strategic research that is designed to monitor, analyze and evaluate the realtime environment, forecast trends in the development of individual components of the environment, diagnostics, the state of the environment and the choice of means to regulate deviations of the actual state of the environment from the predicted [8].

An important element for strategic monitoring is the regulatory environment [9] both at the level of legislative acts and at the level of individual scientific developments. In today's very difficult economic conditions of Ukraine, this is particularly important with the strengthening of the role of various examinations, methods of assessing the current and future state of objects at different levels of economic development management, because the possession of reliable and relevant information, along with the ability to maximize the use of adequate methods of its collection, processing, analysis and presentation are the basis of effective activity of the state, the region and business entities.

Such work at the state, regional and local levels, as a rule, has a hierarchical relationship with the characteristics inherent in all hierarchical systems [10], which include:

- sequential vertical subordination of subsystems forming this system (vertical decomposition);

- priority of actions or right of intervention of toplevel subsystems;

- dependence of actions of subsystems of the top level on the actual execution of subsystems of the lower level of their functions.

In this case, the system or subsystem is considered as a process of converting input parameters into output ones.

On the basis of the above provisions, we consider it appropriate to identify a hierarchy of levels of strategic monitoring in the system of national economic security, namely (fig. 1):

- mega level (global or world level);

- macro level (state, national level);

- meso level (regional level);

- micro level (local level, level of subjects).

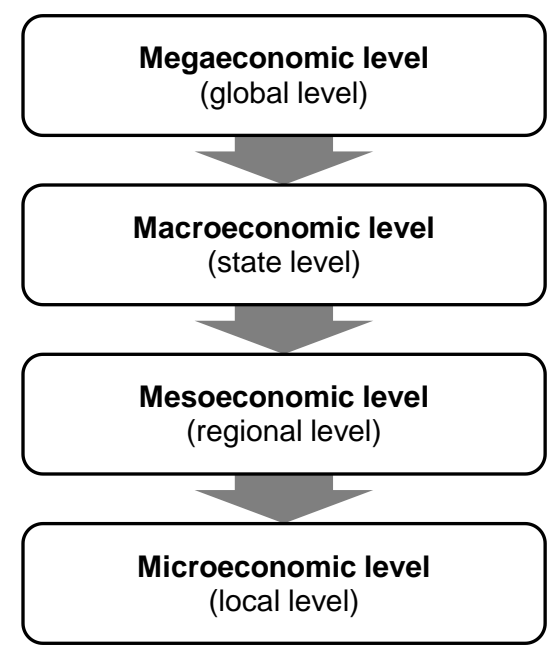

Fig. 1. The hierarchy of levels of strategic monitoring

The formation of information flows should be carried out at all levels. Accordingly, the levels of strategic monitoring organizations are characterized by:

- quantitative and qualitative composition of the analyzed information;

- the nature of the self-organization of this level of activity, the degree of its centralization (decentralization);

- the ratio of economic and administrative (noneconomic) mechanisms of regulation of activities of entities of this level;

- the nature of relations between actors (relations of the hierarchy, equality, etc.);

- the reaction rate of subjects of this level of activity on the influence of factors of the environment;

- the characteristics of the flows of information that function at this level of the hierarchy (volume, diversity, complexity);

- the potential ("throughput") of subjects of the given level of the hierarchy in the field of collection, processing, storage and transmission of information [11]. 
In addition, the organization of activities at a certain level of management hierarchy:

- primarily aimed at ensuring the sustainable development of subjects of this level;

- associated with activities on the higher and lower levels of the hierarchy by a system of direct and inverse relationships;
- to a certain extent, affects the activity of the lower level of the hierarchy, and in its turn, its effectiveness at this level depends on the effectiveness of the organization of the lower level of activity [11].

The process of using information of economic entities on the micro, meso and macro levels for the purpose of strategic monitoring and management is schematically shown in fig. 2.

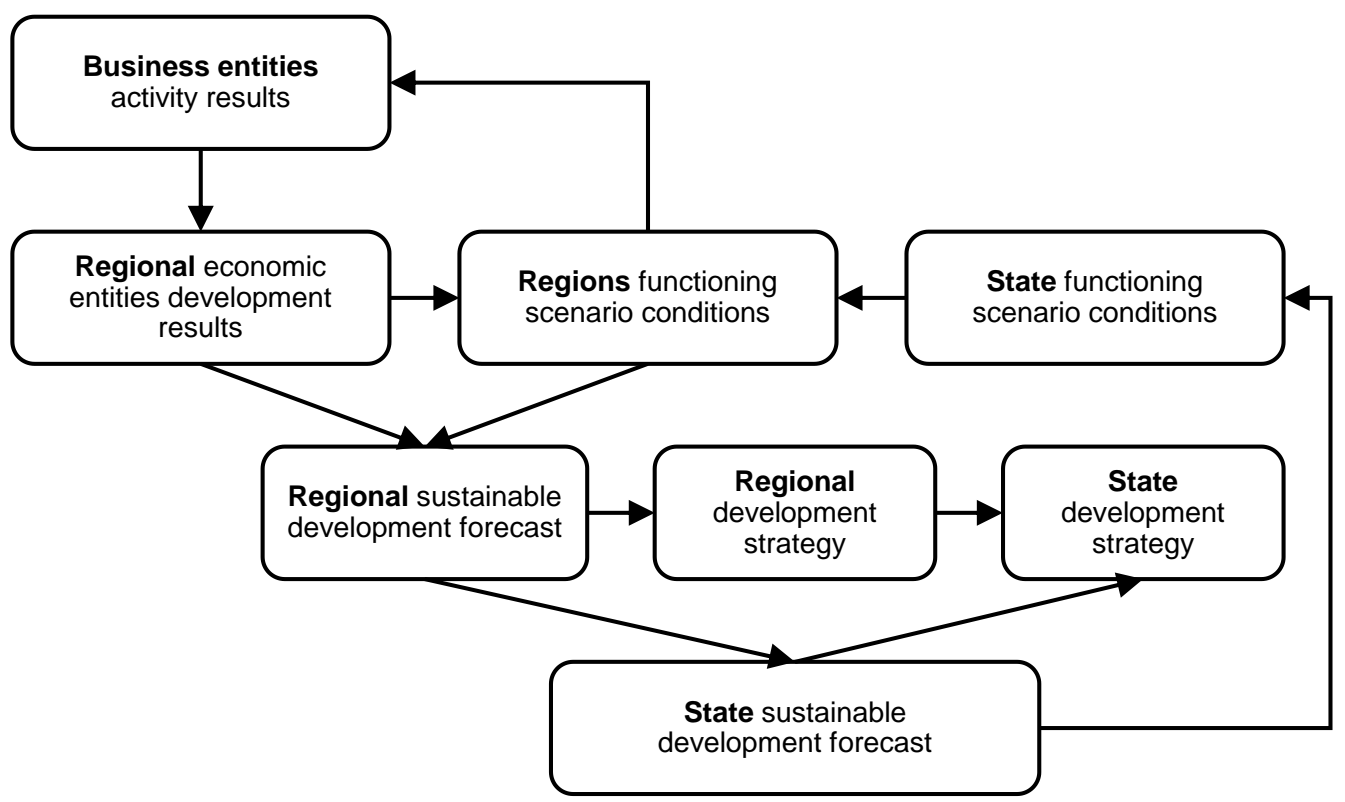

Fig. 2. The process of using information of economic entities of different levels for the purpose of strategic monitoring and management

Thus, the economic security of an entity is shaped by the influence of environmental factors at the global, national and regional levels.

One of the key characteristics of the modern development of global economic processes is globalization. The interdependence of national economies and the interconnection of socio-economic processes in different regions of the world are constantly increasing, which in fact determines the expediency of the analysis of environmental factors at the world level on the level of competitiveness of the country.

At the same time, the competitiveness of the country is considered as a set of properties inherent in the national economy, which determine the ability of the country to compete with other countries. The level of competitiveness of a country is determined by the different methods presented in table 1 .

Table 1. International Competitiveness Ratings: Systematizing Approaches

\begin{tabular}{|c|c|c|}
\hline $\begin{array}{c}\text { Name of rating and the } \\
\text { position of Ukraine }\end{array}$ & Description & Structure \\
\hline $\begin{array}{l}\text { The Global Competitiveness } \\
\text { Index, Ukraine is ranked } 83 \\
\text { out of } 140 \text { (according to The } \\
\text { Global Competitiveness } \\
\text { Report 2018). }\end{array}$ & $\begin{array}{l}\text { Developed by the World Economic } \\
\text { Forum (WEF), Switzerland. Represents } \\
\text { one of the most complete complexes of } \\
\text { competitiveness indicators in different } \\
\text { countries of the world. }\end{array}$ & $\begin{array}{l}98 \text { indicators divided into } 12 \text { groups: quality of } \\
\text { institutions, infrastructure, macroeconomic stability, } \\
\text { health and primary education, higher education and } \\
\text { vocational training, efficiency of the goods and } \\
\text { services market, labor market efficiency, financial } \\
\text { market development, technological development } \\
\text { level, size the domestic market, the competitiveness } \\
\text { of companies, the innovation potential. }\end{array}$ \\
\hline $\begin{array}{l}\text { World Competitiveness } \\
\text { Ranking - Ukraine is ranked } \\
\text { 59th out of } 63 \text { (according to } \\
\text { World Competitiveness } \\
\text { Rankings 2018). }\end{array}$ & $\begin{array}{l}\text { Published by the World } \\
\text { Competitiveness Center at the Institute } \\
\text { for Management Development } \\
\text { (Switzerland) in the World } \\
\text { Competitiveness Yearbook. }\end{array}$ & $\begin{array}{l}\text { More than } 340 \text { indicators according to } 52 \text { research } \\
\text { institutes in the world, divided into } 4 \text { groups: state of } \\
\text { the economy, government efficiency, state of the } \\
\text { business environment, state of infrastructure. }\end{array}$ \\
\hline $\begin{array}{l}\text { The Global Sustainable } \\
\text { Competitiveness Index - } \\
\text { Ukraine is ranked 91st out of } \\
180 \text { (according to The Global } \\
\text { Competitiveness Report } \\
\text { 2017). }\end{array}$ & $\begin{array}{l}\text { Designed by the Swiss-Korean Joint } \\
\text { Venture SolAbility. Measures the } \\
\text { current and future capabilities of } \\
\text { national economies to generate and / or } \\
\text { maintain financial and non-financial } \\
\text { incomes and wealth of their populations. }\end{array}$ & $\begin{array}{l}111 \text { indicators based on World Bank, International } \\
\text { Monetary Fund and UN data are aggregated into } 5 \\
\text { subindices: natural capital, social capital, resource } \\
\text { management, intellectual management, and } \\
\text { government efficiency. }\end{array}$ \\
\hline
\end{tabular}


Tne end of the Table 1

\begin{tabular}{|c|c|c|}
\hline $\begin{array}{l}\text { Ease of Doing Business Index } \\
\text { - Ukraine is ranked 71st out } \\
\text { of } 190 \text { (according to Doing } \\
\text { Business 2019). }\end{array}$ & $\begin{array}{l}\text { Created by the World Bank Group. } \\
\text { Allows you to objectively evaluate the } \\
\text { legislation related to business } \\
\text { regulation, and its application in } 190 \\
\text { countries, as well as in selected cities } \\
\text { and regional levels. }\end{array}$ & $\begin{array}{l}\text { Analyzes the legal rules applicable to enterprises in } \\
11 \text { areas: establishment of enterprises, obtaining } \\
\text { construction permits, connection to the electricity } \\
\text { supply system, registration of property, obtaining } \\
\text { loans, protection of minority investors, taxation, } \\
\text { international trade, enforcement of contracts, } \\
\text { insolvency and regulation the labor market. }\end{array}$ \\
\hline $\begin{array}{l}\text { Index of Economic Freedom - } \\
\text { Ukraine is ranked } 147 \text { th out } \\
\text { of } 180 \text { and is in a group of } \\
\text { countries with a "mostly non- } \\
\text { free economy" (according to } \\
\text { the } 2019 \text { Index of Economic } \\
\text { Freedom). }\end{array}$ & $\begin{array}{l}\text { Calculated by the American research } \\
\text { center The Heritage Foundation in } \\
\text { collaboration with The Wall Street } \\
\text { Journal and assesses the level of } \\
\text { liberalization of the interaction between } \\
\text { the state and business. All countries of } \\
\text { the world are divided into } 5 \text { contingent } \\
\text { groups - "with a free economy", "with a } \\
\text { predominantly free economy", "with a } \\
\text { moderately free economy", "mostly } \\
\text { non-free economy" and "with a non-free } \\
\text { economy". }\end{array}$ & $\begin{array}{l}12 \text { quantitative and qualitative indicators (formerly } \\
\text { 10), grouped under the four components of economic } \\
\text { freedom: the rule of law; government restrictions; } \\
\text { regulatory efficiency; market openness. The index } \\
\text { takes values from } 0 \text { (worst value) to } 100 \text { (best). }\end{array}$ \\
\hline
\end{tabular}

The Global Competitiveness Index GCI 4.0 [12], almost 40 years after the first annual assessment of the world economy, is estimated by the World Economic Forum on a new methodology that allows the fullest possible account to be taken of the impact of the fourth industrial revolution on the development of economies in the world in 12 groups: environmental friendliness ( institutions, infrastructure, implementation of ICT, macroeconomic stability); human capital (health, qualification); markets (market of goods, labor market, financial system, market capacity); ecosystem innovation (business dynamics, innovation capacity). The average score of GCI 4.0 for the world economy in 2018 is 60.40 points. The first place in the rating is occupied by the United States. They are followed by Singapore, Germany, Switzerland, Japan, the Netherlands, Hong Kong, the United Kingdom, Sweden and Denmark. The last place in the ranking is occupied by Haiti, Yemen and Chad.

The positions of Ukraine in comparison with some countries of the world under the index GCI 4.0 is given in the table 2 .

Table 2. Positions of Ukraine and some countries of the world according to the Global Competitiveness Index

\begin{tabular}{|l|c|c|c|c|c|c|c|}
\hline States & $\begin{array}{c}2012 \\
\text { (among 144 } \\
\text { countries) }\end{array}$ & $\begin{array}{c}2013 \\
\text { (among 148 } \\
\text { countries) }\end{array}$ & $\begin{array}{c}2014 \\
\text { (among 144 } \\
\text { countries) }\end{array}$ & $\begin{array}{c}2015 \\
\text { (among 140 } \\
\text { countries) }\end{array}$ & $\begin{array}{c}2016 \\
\text { (among 138 } \\
\text { countries) }\end{array}$ & $\begin{array}{c}2017 \\
\text { (among 137 } \\
\text { countries) }\end{array}$ & $\begin{array}{c}2018 \\
\text { (among 140 } \\
\text { countries) }\end{array}$ \\
\hline Ukraine & 73 & 84 & 76 & 79 & 85 & 81 & 83 \\
\hline Georgia & 77 & 72 & 69 & 66 & 59 & 67 & 66 \\
\hline Russia & 67 & 64 & 53 & 45 & 43 & 38 & 43 \\
\hline Turkey & 43 & 44 & 45 & 51 & 55 & 53 & 61 \\
\hline Poland & 41 & 42 & 43 & 41 & 36 & 39 & 37 \\
\hline
\end{tabular}

Poland is in the 37 th place, Hungary is 48 , Slovakia - 41, Romania - 52, Turkey - 61, Moldova - 88. Russia is ranked the 43rd place, rising by two lines compared to last year.

The components that reduce Ukraine's performance were Macroeconomic Stability (131st place), Financial System (117th place) and Institutions (110th place). Among the indicators for which Ukraine received low marks, in particular, are: the impact of organized crime on the cost of doing business, the level of inflation (average for 2016-2017 years), the dynamics of debt, taking into account the country's credit rating, the level of terrorism, the independence of the judicial system, protection property rights, road quality, the impact of taxes and subsidies on competition, the flexibility of setting salaries, financing small and medium-sized businesses, the reliability of banks, the share of problem loans, the growth rate of innovation companies.

IMD's global competitiveness rating [13] is based on the assessment of the state of the country's economy, the efficiency of public authorities, the state of the business environment and the state of infrastructure. The first place in the 2018 ranking was the United States. Ex-Hong Kong ranked the second. Three leaders, like last year, are completing Singapore. Ukraine has moved from the 60th to 59th place from 63 countries and three positions ahead of Mongolia and still lags behind Russia by 14 positions.

The Global Sustainable Competitiveness Index [14] is developed by the Swiss-Korean joint venture SolAbility to assess the current and future ability of countries and their economies to create and maintain financial and nonfinancial income for their populations. In the ranking for this index, Ukraine ranked 91st out of 180.

According to the Index of ease of doing business [15], Ukraine ranks 71st out of 190 countries (between Kyrgyzstan and Greece), which is 5 positions higher compared to the Doing Business-18 ranking.) Ukraine ranks the 71st out of 190 countries (between Kyrgyzstan and Greece), which is 5 positions higher in comparison with the rating of Doing Business-2018. Ukraine has 
shown the greatest growth in the nominations for "international trade" and "fulfillment of contractual obligations". New Zealand (86.59 points), Singapore (85.24) and Denmark (84.64) ranked the top three leaders in the ranking of ease of doing business.).

The Index of Economic Freedom [16] is an instrument for in-depth analysis of economies around the world and is calculated by the American research center The Heritage Foundation in collaboration with The Wall Street Journal on the basis of 12 indicators, grouped into four broad categories, or pillars of economic freedom According to the results of the full ranking, all countries in this index are divided into 5 conditional groups - "with a free economy", "with a predominantly free economy", "with a moderately free economy", "mostly non-free economy" and "with a non-free economy". The first group of countries with a free economy included countries that scored more than 80 points: Hong Kong, Singapore, New Zealand, Switzerland, Australia and Ireland. Recent ranking positions were taken by Nigeria, Sudan, Chad, Central African Republic, Angola, Ecuador, Suriname, Timor-Leste, Togo, Turkmenistan, Mozambique, Djibouti, Algeria, Bolivia, Zimbabwe, Equatorial Guinea, Eritrea, Congo, Cuba, Venezuela and North Korea. as countries where economic freedom is suppressed or absent altogether.

According to this year's study, Ukraine scored 52.3 points out of 100 possible and ranked the 147th out of 180 countries (the last position among 44 European countries) in a group of countries with a "mostly non-free economy". The dynamics of the index of economic freedom of Ukraine is shown in fig. 3 .

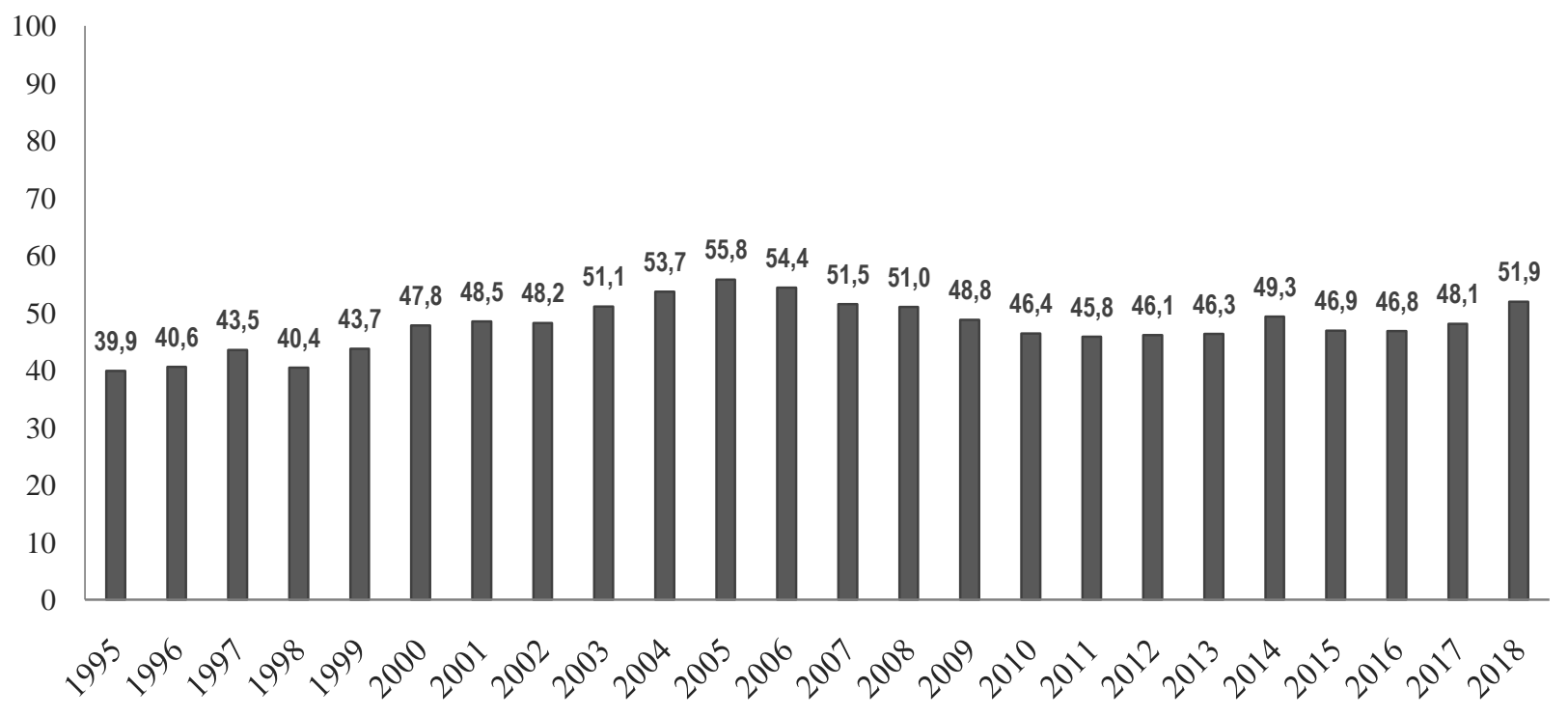

Fig. 3. The dynamics of the index of economic freedom of Ukraine for 1995-2018 years

Over the past year, the Index of Economic Freedom of Ukraine has grown by 3.8 points, thanks to positive changes in the assessment of monetary freedom and freedom of investment. Instead, three indicators of Ukraine are rated worse than last year, namely property rights, government integrity and freedom of trade, indicating the need to fight corruption, capital markets, privatization of state-owned enterprises, and the improvement of the legislative framework and the rule of law.

\section{Conclusions from this study}

In the context of the main trends of globalization, the effectiveness of ensuring national security, including the fight against international terrorism, cross-border crime; migration regulation; provision of social services; market regulation; control over the extraction of natural resources, etc., is based on the active participation of the country in the regional and global integration processes.

In this regard, the problems of research into threats to national interests and national security of Ukraine were reformed to reform all spheres of public life within the framework of the European integration course. First of all, global trends are potentially sources of threats to national security. These include: the intensification of competition between world centers of force, the strengthening of competition for raw materials resources for access to them and control over the routes of their delivery to the consumption markets; intensification of labor migration;

Thus, according to the results of the study, the hierarchical structure and functional content of the strategic monitoring information system was improved to ensure the financial and economic security of the state, region, economic entities taking into account international competitiveness ratings of the countries by identifying the sources of threats (both internal and external) national Ukraine's security and Ukraine's positioning on components of world-class competitiveness in comparison with other countries. Such an approach allows determining the ways of increasing competitive advantages for the formation of strategic priorities for ensuring economic security of economic entities in the conditions of Ukraine's integration into European political, economic, security, legal space, membership of 
the European Union and the North Atlantic Treaty Organization, the development of equal, mutually beneficial relations with other states.

In the context of the current challenges and threats to regional security, Ukraine's cooperation with regional partners in implementing sound macroeconomic policies and restoring confidence in the financial sector is the most important priority of foreign policy. According to international competitiveness ratings, it is first of all necessary to concentrate efforts on combating corruption, which is defined in Article 3 of the Association
Agreement with the EU as one of the main principles for strengthening relations between Ukraine and the EU.

Strategic monitoring in the system of providing financial and economic security of the state, region, business entities within the framework of system analysis and forecasting changes in global competitiveness of the world should become a significant measure of the system and complex implementation of the system of counteracting threats to ensure the protection of the realization of the national interests of the state as the basis viability and conditions for further progressive development of our country.

\section{References}

1. Bilyk, R. I. (2013), "Economic security of the region in the system of modern regional policy of Ukraine" ["Ekonomichna bezpeka rehionu u systemi suchasnoi rehionalnoi polityky Ukrainy"], Visnyk Akademii pratsi $i$ sotsialnykh vidnosyn Federatsii profspilok Ukrainy, No. 2, P. 31-37.

2. Vlasiuk, O. S. (2010), State economic security system [Systema ekonomichnoi bezpeky derzhavy], Stylos, Kyiv, 684 p.

3. Krylenko, I. V. (2013), "Economic security of the region as a component of national economic security" ["Ekonomichna bezpeka rehionu yak skladova zabezpechennia natsionalnoi ekonomichnoi bezpeky"], Efektyvna ekonomika, available at: http://www.economy.nayka.com.ua/?op=1\&z=1779 (last accessed 01.03.2019).

4. Muntiian, V. I. (1999), Economic security of Ukraine [Ekonomichna bezpeka Ukrainy], KVITs, Kyiv, 462 p.

5. Predborskyi, V. A. (2005), Economic security of the state: a monograph [Ekonomichna bezpeka derzhavy: monohrafiia], Kondor, Kyiv, 391 p.

6. Sak, T. V. (2013), "Economic security of Ukraine: concept, structure, main tendencies" ["Ekonomichna bezpeka Ukrainy: poniattia, struktura, osnovni tendentsii"], Innovatsiina ekonomika, No. 6 (44), P. 336-340.

7. Tymoshenko, O. V. (2016), Economic security of the national economy in the globalization conditions: a monorgaph [Ekonomichna bezpeka natsionalnoi ekonomiky v umovakh hlobalizatsii : monohrafiia], TOV "Nash format", Kyiv, 384 p.

8. Shershnova, Z. Ye. (2004), Strategic Management: Textbook [Stratehichne upravlinnia: Pidruchnyk], 2nd ed., KNEU, Kyiv, $699 \mathrm{p}$.

9. Chekh, N. O., Vashchenko, O. M. (2017), "Regulatory environment of business activities in Ukraine", Innovative Technologies and Scientific Solutions for Industries, No. 1 (1), P. 124-129. DOI: https://doi.org/10.30837/2522-9818.2017.1.124.

10. Mesarovich, M., Mako, D., Takakhara, I. (1973), Theory of Hierarchical Multilevel Systems [Teoriya ierarkhicheskikh mnogourovnevykh sistem], Mir, Moscow, 344 p.

11. Kulytskyi, S. P. (2002), Fundamentals of information management in the field of management: Teaching manual [Osnovy orhanizatsii informatsiinoi diialnosti u sferi upravlinnia : Navch. posib.], MAUP, Kyiv, 224 p.

12. The Global Competitiveness Report 2018, available at : http://www.weforum.org/reports/the-global-competitveness-report-2018 (last accessed 01.03.2019).

13. World Competitiveness Ranking 2018, available at: http://www.imd.org/wcc/world-competitiveness-center-rankings/worldcompetitiveness-ranking-2018/ (last accessed 01.03.2019).

14. The Global Sustainable Competitiveness Index, available at: http://solability.com/the-global-sustainable-competitivenessindex/the-index (last accessed 01.03.2019).

15. Doing Business, available at : http://www.doingbusiness.org/ (last accessed 01.03.2019).

16. 2019 Index of Economic Freedom, available at : http://www.heritage.org/index/ (last accessed 01.03.2019).

Received 27.02.2019

\section{Вiдомості про авторів / Сведения об авторах / About the Authors}

Момот Тетяна Валеріївна - доктор економічних наук, професор, Харківський національний університет міського господарства імені О. М. Бекетова, завідувач кафедри фінансово-економічної безпеки, обліку і аудиту, м. Харків, Україна; e-mail: tvmomot@gmail.com; ORCID ID: http://orcid.org/0000-0001-7397-3565.

Момот Татьяна Валерьевна - доктор экономических наук, профессор, Харьковский национальный университет городского хозяйства имени А. Н. Бекетова, заведующая кафедры финансово-экономической безопасности, учета и аудита.

Momot Tetiana - Doctor of Sciences (Economics), Professor, O. M. Beketov Kharkiv National University of Urban Economy, Head at the Department of Financial and Economic Security, Accounting and Auditing, Kharkiv, Ukraine.

Ващенко Олександр Миколайович - кандидат економічних наук, Харківський національний університет міського господарства імені О. М. Бекетова, доцент кафедри фінансово-економічної безпеки, обліку і аудиту, Харків, Україна; e-mail: vashchenko_an@yahoo.com; ORCID ID: http://orcid.org/0000-0003-3027-7644.

Ващенко Александр Николаевич - кандидат экономических наук, Харьковский национальный университет городского хозяйства имени А. Н. Бекетова, доцент кафедры финансово-экономической безопасности, учета и аудита, Харьков, Украина.

Vashchenko Oleksandr - PhD (Economics Sciences), O. M. Beketov National University of Urban Economy, Associate Professor at the Department of Financial and Economic Security, Accounting and Auditing, Kharkiv, Ukraine. 
Тесленко Роман Юрійович - Харківський національний університет міського господарства імені О. М. Бекетова, аспірант кафедри фінансово-економічної безпеки, обліку і аудиту, Харків, Україна; e-mail: roman.tslnk@gmail.com; ORCID ID: http://orcid.org/0000-0001-9008-2959.

Тесленко Роман Юрьевич - Харьковский национальный университет городского хозяйства имени А. Н. Бекетова, аспирант кафедры финансово-экономической безопасности, учета и аудита, Харьков, Украина.

Teslenko Roman - O. M. Beketov Kharkiv National University of Urban Economy, Post-Graduate Student at the Department of Financial and Economic Security, Accounting and Auditing, Kharkiv, Ukraine.

Момот Дарина Тарасівна - Харківський національний університет міського господарства імені О. М. Бекетова, аспірант кафедри фінансово-економічної безпеки, обліку і аудиту, Харків, Україна; e-mail: momotdaryna@gmail.com; ORCID ID: http://orcid.org/0000-0002-6026-541X.

Момот Дарина Тарасовна - Харьковский национальный университет городского хозяйства имени А. Н. Бекетова, аспирант кафедры финансово-экономической безопасности, учета и аудита, Харьков, Украина.

Momot Daryna - O. M. Beketov Kharkiv National University of Urban Economy, Post-Graduate Student at the Department of Financial and Economic Security, Accounting and Auditing, Kharkiv, Ukraine.

\section{СТРАТЕГІЧНИЙ МОНІТОРИНГ ЗОВНІШНЬОГО СЕРЕДОВИЩА В СИСТЕМІ ЗАБЕЗПЕЧЕННЯ ФІНАНСОВО-ЕКОНОМІЧНОЇ БЕЗПЕКИ ДЕРЖАВИ, РЕГІОНУ, СУБ'СКТІВ ГОСПОДАРЮВАННЯ}

Предметом дослідження в статті є комплексний аналіз зовнішнього середовища за рівнем конкурентоспроможності країни. Мета роботи - поглиблення науково-методичних засад комплексного аналізу зовнішнього середовища за рівнем конкурентоспроможності країни в рамках стратегічного моніторингу в системі забезпечення фінансово-економічної безпеки держави, регіону, суб'єктів господарювання. В статті вирішуються наступні завдання: обгрунтовано ієрархічність зв'язків у процесі здійснення стратегічного моніторингу в системі забезпечення фінансово-економічної безпеки держави, регіону, суб'єктів господарювання; розглянуто ієрархію рівнів стратегічного моніторингу в системі національної економічної безпеки; охарактеризовані інформаційні потоки рівнів організації стратегічного моніторингу; описано процес використання інформації економічними суб'єктами на різних рівнях управління 3 метою здійснення стратегічного моніторингу; систематизовано міжнародні підходи до побудови рейтингів конкурентоспроможності країн; проаналізовано місце України в міжнародних рейтингах конкурентоспроможності. Використовуються такі методи: абстрактно-логічний аналіз, теоретичного узагальнення, системного та статистичного аналізу. Отримано наступні результати: доведено, що стратегічний моніторинг на державному, регіональному та місцевому рівнях, як правило, має ієрархічний зв'язок з притаманними всім ієрархічним системам характеристиками; фінансово-економічна безпека будь-якого економічного суб'єкта формується під впливом факторів зовнішнього середовища глобального, національного та регіонального рівнів; конкурентоспроможність країни розглядається як сукупність властивостей, притаманних національній економіці, які визначають здатність країни конкурувати з іншими країнами; за результатами аналізу ключових міжнародних рейтингів конкурентоспроможності країни встановлено, що Україні для забезпечення фінансово-економічної безпеки на різних рівнях передусім необхідно сконцентрувати зусилля на боротьбі 3 корупцією та здійсненні раціональної макроекономічної політики. Висновки: стратегічний моніторинг в системі забезпечення фінансово-економічної безпеки держави, регіону, суб'єктів господарювання в межах проведення системного аналізу і прогнозування змін глобальної конкурентоспроможності країн світу має стати вагомим заходом системно-комплексної реалізації системи протидії наявним загрозам для забезпечення захисту реалізації національних інтересів держави як основи життєздатності та умови подальшого прогресивного розвитку країни.

Ключові слова: стратегічний моніторинг; конкурентоспроможність країни; фінансово-економічна безпека; міжнародн рейтинги конкурентоспроможності; комплексний аналіз.

\section{СТРАТЕГИЧЕСКИЙ МОНИТОРИНГ ВНЕШНЕЙ СРЕДЫ В СИСТЕМЕ ОБЕСПЕЧЕНИЯ ФИНАНСОВО-ЭКОНОМИЧЕСКОЙ БЕЗОПАСНОСТИ ГОСУДАРСТВА, РЕГИОНА, ПРЕДПРИЯТИЯ}

\footnotetext{
Предметом исследования в статье является комплексный анализ внешней среды по уровню конкурентоспособности страны. Цель работы - обоснование научно-методических основ комплексного анализа внешней среды по уровню конкурентоспособности страны в рамках стратегического мониторинга в системе обеспечения финансово-экономической безопасности государства, региона, субъектов хозяйствования. В статье решаются следующие задачи: обоснованно иерархичность связей в процессе осуществления стратегического мониторинга в системе обеспечения финансовоэкономической безопасности государства, региона, субъектов хозяйствования; рассмотрена иерархия уровней стратегического мониторинга в системе национальной экономической безопасности; охарактеризованы информационные потоки уровней организации стратегического мониторинга; описан процесс использования информации экономическими субъектами на различных уровнях управления с целью осуществления стратегического мониторинга; систематизированы международные подходы к построению рейтингов конкурентоспособности стран; проанализировано место Украины в международных рейтингах конкурентоспособности. Используются следующие методы: абстрактно-логический анализ, теоретического обобщения, системного и статистического анализа. Получены следующие результаты: доказано, что стратегический мониторинг на региональном и местном уровнях, как правило, имеет иерархический характер связи с присущими всем иерархическим системам характеристиками; экономическая безопасность любого экономического субъекта формируется под влиянием факторов внешней среды глобального, национального и регионального уровней; конкурентоспособность страны рассматривается как совокупность свойств, присущих национальной экономике, которые определяют способность страны конкурировать с другими странами; по результатам анализа ключевых международных
} 
рейтингов конкурентоспособности страны установлено, что Украине для обеспечения финансово-экономической безопасности на разных уровнях прежде всего необходимо сконцентрировать усилия на борьбе с коррупцией и осуществлении рациональной макроэкономической политики. Выводы: стратегический мониторинг в системе обеспечения финансово-экономической безопасности государства, региона, субъектов хозяйствования в рамках проведения системного анализа и прогнозирования изменений глобальной конкурентоспособности стран мира должен стать важным мероприятием системно-комплексной реализации противодействия имеющимся угрозам для обеспечения защиты реализации национальных интересов государства как основы жизнеспособности и важного условия дальнейшего прогрессивного развития страны.

Ключевые слова: стратегический мониторинг; конкурентоспособность страны; финансово-экономическая безопасность; международные рейтинги конкурентоспособности; комплексный анализ. 